\title{
Turkey as A Determinant Factor Stabilizing the Middle East
}

\section{Shokhan Sherzad Qader}

PhD Student, Department of Political Science, Faculty of Law, Political Science and Management, Soran University, Soran, Iraq shokhan.sherzad@gmail.com

\section{Prof. Dr. Mohammed Ihsan}

Senior Research Fellow at Defense Studies Research, King's College, London, England mohammed.ihsan@ue.edu.krd

\section{ARTICLE INFO}

\section{Article History:}

Received: $10 / 7 / 2020$

Accepted: 16/9/2020

Published: Summer 2020

\section{Keywords: Cold War,} Turkey, Middle East, Regional Power, Foreign Policy, JDP

Doi:

10.25212/lfu.qzj.5.3.35

\begin{abstract}
The aim of this study is to identify whether Turkey can be a determinant factor in stabilizing the Middle East. The role of Turkey as a regional power has increased from the time Justice and Development Party (JDP) ascended to power. The leadership of JDP did not just aspire to be a regional power but a global power. Thus, Turkey assumed various roles, like being an accepted leader within the region, a big brother historically, plus a shield of Muslim subgroups. Other roles that Turkey has obtained are those of a facilitator and mediator with its attempt to create stability within Iraq, Syria, and within the entire Middle East.
\end{abstract}

The method that was used in gathering the research is qualitative and use of secondary sources. Sieving through the previous works conducted by other authors, the researcher managed to obtained relevant material and used it to contextualize the study and explain how Turkey is playing an eminent role in stabilizing the Middle East. 


\section{QALAAI ZANISTSCIENTIFIC JOURNAL \\ A Scientific Quarterly Refereed Journal Issued by Lebanese French University - Erbil, Kurdistan, Iraq \\ Vol. (5), No (3), Summer 2020 \\ ISSN 2518-6566 (Online) - ISSN 2518-6558 (Print)}

In light of the current research study, Turkey has made various efforts in improving relations with its Neighbors and has played a mediator role within the Middle East. Through foreign policy, Turkey has bolstered good relations within Middle East.

To enhance stabilization in the Middle East, Turkey ought to maintain the good relations with various countries embrace the challenges emanating from its role. Ideally, good relationships in the political realm provide a favorable environment for countries that seek to unite warring nations. Hence, Turkey should ensure good relations to bolster stabilization in the Middle East.

The contribution of this research paper lies within the analysis bringing the wide range of descriptions in the literature together, discovering samples and examples regarding Turkey as a mediator role since JDP government, and tried to bring all of these literature in a piece of work, therefore this would be a path for other researchers to study and analyze more in future studies.

\section{INTRODUCTION}

Due to the location of the Middle East, the researchers have always focused on this region in their studies. Middle East similar to any region each actor has different dynamics and activities, and care for their relations with the neighbors in different levels and directions. The Middle East occupies an essential place in the Turkish foreign policy (Ari and Pirinççi, 2010). This is due to the many outstanding external and internal processes. Basing on past governments' accomplishments, like a failure in Kurdistan Workers' Party (PKK) activities after the arrest of Ocalan, improved relations with Iraq and repeated Justice and Development Party (JDP) governments have got back to hastening democratization and quick economic development 


\section{QALAAI ZANISTSCIENTIFIC JOURNAL \\ A Scientific Quarterly Refereed Journal Issued by Lebanese French University - Erbil, Kurdistan, Iraq \\ Vol. (5), No (3), Summer 2020 \\ ISSN 2518-6566 (Online) - ISSN 2518-6558 (Print)}

progression. Ari and Pirinççi (2010) argue that, in an era, Turkey has changed to being a significant player within the region considering the political, economic, and expansive levels by establishing relations with Iran, Syria, Saudi Arabia, and many others accompanied by robust relationships with Israel. As such, Turkey has continued to be active in North Africa and the Middle East, attempting to be one of the upper actors in each relevant issue.

The current research paper will focus on how Turkey could play as a determinant factor in stabilizing the Middle East majorly during JDP's governing period and how Turkey's stability is related to the Middle East region. The study argues that Turkey is a favorable determinant factor in stabilizing the Middle East despite all counterarguments regarding JDP's foreign policy, and Turkey had made real attempts in bringing stability and playing mediator roles.

The significance of the study is that the study is relevant because it brings out why it is important to consider Turkey as being a determinant factor in stabilizing the Middle East. In getting the results in the research, the study applied the qualitative method and used secondary resources.

The time frame of the study is from 2002 to 2018. The first part will be on the historical and theoretical background of Turkish engagement towards the Middle East. The second part will focus on Turkey and the stability of the Middle East. Further, the third part will be a valuation of Turkey's engagement in the Middle East since 2002, and this will include examples and explanations with neighbors and the Middle East. Lastly, the researcher will give an insightful conclusion and recommendations.

\section{II.Theoretical and Historical Backgrounds}

During the Cold War, the Middle East did not receive much weight regarding Turkish Foreign Policy. Hale (2012) explained that from the late 1980s, many internal and external developments needed rethinking of the Turkish Foreign policy to the region, which later resulted in further participation. The Gulf Crisis of 1990-1991 came up 


\section{QALAAI ZANISTSCIENTIFIC JOURNAL \\ A Scientific Quarterly Refereed Journal Issued by Lebanese French University - Erbil, Kurdistan, Iraq \\ Vol. (5), No (3), Summer 2020 \\ ISSN 2518-6566 (Online) - ISSN 2518-6558 (Print)}

when Turkey was not sure regarding its position in the current emergent post-Cold War international system (Hale, 2012). Therefore, Ankara has the hope of reiterating its planned importance by giving support to Washington's Iraq Policy. Hitherto, Iraq developments when the war was over created more problems in terms of security for Turkey. The Kurdish question got affected by the backing offered to PKK majorly through Syria up to 1998 and Iran in the 1990s (Sayari, 1997). Therefore, because of the effects of developments in the Middle East regarding Turkey's Kurdish challenge, Turkey felt the importance of engaging in the Middle East (Robins, 2014).

Over the 1990s, Turkey was significantly involved with Northern Iraq through the use of various tools like soldierly means and cooperating with the US. However, in that decade, the relationships of Turkey with Iraq worsened due to the Kurdish matter. Also, Turkey engaged in aligning itself with Israel, and then signed two contracts meant for military support so it could balance the threats from the neighbors of the Middle East (Robins, 2014).

In 2002, when the Justice and Development Party emanated to power, the involvement of Turkey within the Middle East started going beyond the Kurdish issue. It changed its turn to a more resourceful one. JDP worked towards Turkey to be more involved and advocate for a "zero problem with neighbors" (Kardaş, 2012, p.12). From such a perspective, Turkey's soft power abilities plus economic chances began being emphasized than the military skills. Thus, with JDP being in power, cultural and historical ties became emphasized with the Middle East then enhanced Turkey's engagement within the region. The strategy could be employed because of the various changes within the region. The region faced a massive crisis during the 2000s like the fall of Arab-Israeli Peace Process in 2000, decline of the Palestinian conflict, the US invaded Iraq in 2003, Iran rising to the local authority, intra-Arab separations aimed at particular nations such as Syria, the fear of collapse resulted to the regions being weak (Hinnebusch and Hteshami, 2002).

Ari and Pirincci (2010) state that Turkey has created a good impression on the countries of the Middle East plus the third parties through her regional engagement 


\section{QALAAI ZANISTSCIENTIFIC JOURNAL \\ A Scientific Quarterly Refereed Journal Issued by Lebanese French University - Erbil, Kurdistan, Iraq \\ Vol. (5), No (3), Summer 2020 \\ ISSN 2518-6566 (Online) - ISSN 2518-6558 (Print)}

and foreign policies, which have been active. Turkey did give some relevance towards relations with Europe represented as "West" other than the Middle East, referred to as "East." Those states that were created after the Ottoman Empire withdrawn from the Middle East did not become independent. For instance, Iraq and Jordan remained under the British, while Syria and Lebanon were under the French mandate.

A significant result of the current era for the Middle East entailed breaking relationships with obligatory powers, bipolar systems. Also, the Cold War determined the significant assemblies of links. Being part of the Western block, Turkey got a chance to assess the security strategies over the expansion of the Soviet, and then tracked her foreign policy via West viewpoints (Sluglett, 2005). Even when there were issues in the countries, Turkey continued to adhere to the policy on non-involvement and non-interference in any conflict of the Middle East. Therefore, through the Cold War era, a significant attitude that underlined relationships is bipolar systems rather than self-interests (Sluglett, 2005). But as the Cold War ended, geographical and systematic changes came about where the regional nations and Turkey needed to reassess their stands.

Ari and Pirincci (2010) explain that during the first years of post-cold war, Cold War discourse continues to take over the minds of regional countries being hostage, plus various developments drove the region's attention to matters relating to security. Regarding Turkey, the Iraqi invade of Kuwait plus developments after that has a link to PKK's actions, and during the 1990s, Turkey needed to focus more on the issue. And in the 1990s era, Turkey owed to go on with the old responsive strategy towards local expansions and took no active moves and developed initiatives in changing the game structure for individual interest in employing necessary instruments like diplomacy.

Tol (2012) argues that at the start of the 2000s, Turkey could not go on with the noninvolvement strategy. About the Middle East, which was well acknowledged before, Turkey got the ability to drive regional movements and creating friendly relations within regional nations to solve problems that exist as it protects its interests. First, it 


\section{QALAAI ZANISTSCIENTIFIC JOURNAL \\ A Scientific Quarterly Refereed Journal Issued by Lebanese French University - Erbil, Kurdistan, Iraq \\ Vol. (5), No (3), Summer 2020 \\ ISSN 2518-6566 (Online) - ISSN 2518-6558 (Print)}

has to be known that the objectives of Turkish foreign policy to the region are majorly planned and depend on creating stability. In short, the policymakers of Turkey have a focus on particular points like protection on territorial integrity and national unity, expansion of trade relations, keeping regional stability, and having peaceful relationships that are made on trust and not mutual doubts. For the current Turkish policy features to be well understood, the primary principles have to be analyzed (Arı and Pirinççi, 2010).

First, Turkey began pursuing multi-dimensional diplomacy even when JDPcame to power. During the Cold War, first centuries of post-Cold war, political aspects plus joint doubts determined engagement limits. Individually, Turkey pursued a foreign policy that served block benefits, which was debatable towards itself. But due to the effects that came after the Cold War, Turkey began developing diplomacy on a multilateral and mutual basis. From the analysis, Lenore (2009) ascertains that it is not about siding with one part but creating diplomatic relationships with every actor. About Lebanon, Turkey developed diplomatic contacts with each group, particularly Sunnis and Shiites, which entirely appreciate the efforts of Turkey in creating peace and invite troops of Turkey in the UN Interim Force in Lebanon (UNIFIL). Turkey was part of UNIFIL because its soldiers served in south Lebanon after attacks from Israeli in 2006. On a multifaceted stage, the decision of Framework Agreement with Arab League in institutionalizing cooperation and relations via the creation of the TurkishArab Cooperation Forum in 2007 then advance Planned Dialogue with Gulf Cooperation Council (GCC) to an organized context in 2008 are instances of a new age (Lenore, 2009). And with the multidimensional diplomacy, Turkey can balance issues with one another and create peaceful methods during difficult times (Turkish Ministry of Foreign Affairs).

The second aspect is a positive engagement. It is a principle with two aspects. From Criss (2010), because of the robust military power within the regional balance of the Middle East, Turkey makes use and stands on diplomacy to solve issues. The third aspect of this principle, Turkey pursues a positive engagement with every country in 


\section{QALAAI ZANISTSCIENTIFIC JOURNAL \\ A Scientific Quarterly Refereed Journal Issued by Lebanese French University - Erbil, Kurdistan, Iraq \\ Vol. (5), No (3), Summer 2020 \\ ISSN 2518-6566 (Online) - ISSN 2518-6558 (Print)}

the world, plus the marginal and politically distant ones. As such, Turkey can be well informed on the worries and concerns of every country also if it is something minor in the region (Criss, 2010).

Fourth, it has developed an independent foreign policy. Nonetheless, Davutoglu (2011) ascertains that, beneath the Cold War, Turkey exaggerated the perception of the threat and, with no condition, fully supported the approaches of Western foreign policy. Thus, the Middle East perceived Turkey as "gendarme of the West" (Arı and Pirinççi, 2010, p. 4). The perception continued to be there even after the Cold War. And through an acknowledgment from Middle Eastern countries that Turkey's initiatives do not have any European or American interests, it made the approach very positive to Turkey. And lastly, Turkey began evaluating problems in a "win-win strategy." This means that each side would get aid from collaboration. Through several emphases from Turkish Prime Minister Erdogan, matters had to be done in a win-win situation (Davutoglu, 2011). From the setting, previous and current aggression yearned to be defeated not just through control or even bullying but through conciliation. And with such a policy, Turkey emphasizes regional stability on everyone's behalf and a solution to problems as of two-sided to multifaceted entailing significant difficulties such as Palestine problem; the whole area could then profit (Davutoğlu, 2011).

Similarly, Turkey's soft power accompanied and facilitated the new stance of Turkey within the Middle East. Furthermore, it may be observed that Turkey's films and dramas being the soft power elements altered the image of Turkey and inclined insights into Turkey in the Arab Middle East. Additionally, the above features made Turkey be a well-known actor in the region (Dinçer and Kutlay, 2012).

\section{III.Turkey and the stability of the middle east}

In the current years, Turkey has been seen to move ahead of the traditional foreign policy by increasing economic, political, and even cultural appearance in the Middle East. Regarding mediation, diplomacy, and solving regional issues, Turkey has 


\section{QALAAI ZANISTSCIENTIFIC JOURNAL \\ A Scientific Quarterly Refereed Journal Issued by Lebanese French University - Erbil, Kurdistan, Iraq \\ Vol. (5), No (3), Summer 2020 \\ ISSN 2518-6566 (Online) - ISSN 2518-6558 (Print)}

extended its traditional role and stance to improve the prosperity and stability within the region. Also, the democratization process of Turkey and the increase in power of JDP has brought some attention to the Middle East. The country has been perceived as a problem solver in the Middle East due to its foreign policy of late 2002 and 2018 when Erdogan was Prime Minister (Akgün, Perçinoğlu, and Gündoğar, 2010).

An urge to play a third-party role is part of the new feature of Turkey's Middle East Policy, and Cook (2010) argues that it does not match with the long-headed strategy of Turkey not taking part in regional conflicts. Being part of resolving disputes within the region was regarded as a means of easing the re-entry of Turkey to the Middle East, plus helping build respect for Turkey in the West and the Middle East. Turkey has got many third-party roles. Being involved in the Israeli-Syrian condition will further be elaborated below. Also, Turkey has had any involvement in Lebanon. Novosseloff (2015) states that Turkey is also taking part in UNIFIL, which was developed after the Lebanon War in 2006, as stated above. Plus, Qatar, Turkey, stood relevant in brokering the Doha Agreement, which concluded political draw in Lebanon's Government. Also, as has been stated above, Turkey has attempted to facilitate in the facilitation of a resolution of Iranian nuclear matter. It has even attempted to take a beneficial role in Iraq. In 2003, Turkey initiated Iraq's Neighbors Forum, which was afterward enlarged to comprise Iraq. Additionally, Turkey organized an assembly in Istanbul through the involvement of the Sunni leaders who are from Iraq to persuade Sunnis to take part in the 2005 elections.

Turkey's Role in the Negotiations between Syria and Israel

Due to the rapid improvement of the relations that Turkey has with Syria after the crisis of October 1998, Bryant and Hatay (2013) determine that Turkey started passing messages to Israel and Syria, stating that it was ready to bring stability between them when they were ready for it. Turkey was the only one that had good relations with these two sides, which could take that role. Ankara believed that with Israeli and Syria resolving their conflicts, then there would be peace plus stability within the region, and Syria would more be engaged in the politics of the region. Therefore, with such 


\section{QALAAI ZANISTSCIENTIFIC JOURNAL \\ A Scientific Quarterly Refereed Journal Issued by Lebanese French University - Erbil, Kurdistan, Iraq \\ Vol. (5), No (3), Summer 2020 \\ ISSN 2518-6566 (Online) - ISSN 2518-6558 (Print)}

thoughts in mind, Turkey's Government has kept announcing how willing it is to be a mediator when they are both ready (Bryant and Hatay, 2013). Such efforts began very early as of 2004. There are claims that Prime Minister Erdogan got involved individually in the reconciliation and sent communications to the two borders (Altunisik-Benli and Tür, 2006).

The exertions of Turkey were disturbed at that time by Abdullah Gul. The foreign minister in 2004 announced that Turkey could not play the role of being an arbitrator during that time. Syria proposed various secondary discussions with Turkish negotiation. For example, Altunisik-Benli and Tür (2006) state that the prime minister of Israeli, Ehud Olmert, eventually agreed to the offer and told the Turkish side when he visited Turkey in 2008. Olmert, through support from the establishment of security in Israel, did perceive an appointment with Syria as relevant for various regional tactical reasons. No matter the case, Olmert's interest at such a time was right to bring indirect talks among the two countries.

Israeli Palestinian Issue

Turkey has always shown concern regarding the problem in Palestine and has, for some time, requested a negotiation basing on a solution for the two states. Therefore, Ankara supported a Peace Process, which began with the Madrid Conference in 1991. For a long time, Turkey has been offering benevolent and development aid to Palestine, as was mentioned above. Regarding activities of institutions and capacity building, Turkey has provided support for the process of political reform, and the Turkish experts participated in administrative and constitutional efforts of change developed by the Palestinian Authority (Kirisci, 2009). Turkey supported various activities to help end these hostilities through the outbreak of al-Aqsa Intifada and an increase in instability and violence within the region. However, the majority of the efforts that Turkey has put in helping Palestine has not borne many results like reconciling Hams and Fatah. 


\section{QALAAI ZANISTSCIENTIFIC JOURNAL \\ A Scientific Quarterly Refereed Journal Issued by Lebanese French University - Erbil, Kurdistan, Iraq \\ Vol. (5), No (3), Summer 2020 \\ ISSN 2518-6566 (Online) - ISSN 2518-6558 (Print)}

Turkey and the Middle East do have a relationship due to Turkey's growing financial ties with the region. The desire to broaden the region's economic relations is a relevant element of foreign policy in Turkey to the Middle East in the current years. Kemal Kirisci (2009) makes an argument that commercial inspirations are what prejudiced an urge to have "zero problems with neighbors," the more Turkey became a "trading state" (Kirisci, 2009, p. 29-56). The economy of Turkey has grown rapidly in the current years. This has been because of two apparent trends. First is that all over Anatolia, industries have spread plus regionalization and diversification. The second trend is that earlier in the current world financial crisis; Turkey already had fast progress in the service and industrial sectors. The developments signified the rising relevance of regional trade. Turkey's trade to the Middle East began being serious as the global financial crisis of 2018 arose and assisted Turkey in easing the negative effects of this crisis on the trade balance (Sözen, 2010). Additionally, other than Iran and Qatar, Turkey's trade balance within countries of the Middle East was entirely in favor of Turkey. At that similar time, Turkey is a partner and well established towards the growth of the Middle East private sector (Davutoglu, 2013).

An argument from Albarracín (2012) is that majority of fiscal and political authorities of countries in the Middle East look at Turkey's experience being a possible model that should be followed. It is true for those small states hopeful of benefitting from a particular spillover impact by improving their economy's linkage towards Turkey. Up to now, most political actors majorly the political ones have incorporated policies active in strengthening the ties of their countries to Turkey, and their Turkey correspondents have been receptive towards such efforts. To prove that, the fluidity of the political relationships among the Middle East and Turkey can be seen through the fact that from 2003 to 2011, the Turkey Prime Minister, Erdogan, visited many countries within the Middle East (Albarracín, 2012).

Additionally, Albarracin (2012) asserts that Turkey has also been a building block for regional interdependence in terms of infrastructure. Recently, with Turkey's economic relations growing regionally within the Middle East, it has been boosted by 


\section{QALAAI ZANISTSCIENTIFIC JOURNAL \\ A Scientific Quarterly Refereed Journal Issued by Lebanese French University - Erbil, Kurdistan, Iraq \\ Vol. (5), No (3), Summer 2020 \\ ISSN 2518-6566 (Online) - ISSN 2518-6558 (Print)}

infrastructure projects which increasingly incorporate and serve as being a support for the entire region through reinforcing its growing interdependence. Some of those regional infrastructure developments which have been completed and others in progress, for instance, Energy infrastructure: the gas and oil pipeline networks that link energy resources of Iraq to Europe through Turkey and resources of Egypt to markets in Europe through Jordan, Turkey and Syria (Albarracín, 2012).

Turkey has a very fundamental role. And this is due to many reasons. Being a country in the region, Turkey's concern is too troubled with each part of the land compared to any other country (Cook, Sabbagh, and Gwetzman, 2011). The activism of Turkey and its reliance on soft power within the region has built for over a decade now. Besides, the current generation made of diplomats, business people, and even television stars is entirely making a connection around the region which will create enduring and deep relationships (Yörük and Vatikiotis, 2013). Although, an official diplomat from Turkey says that "if some people state that the economy would be the major path towards expansion, I would add that security is also relevant" (Cengiz, 2011, p. 64). This means that the security measures of foreign policy creativities are considered. Turkey wanted to be very active in the region like another official stated, Turkey needs stability being a country that has undergone regional disorder and that which "imported many problems in terms of security from the Middle East, terrorist training and arms" (Cengiz, 2011, p. 67). Therefore, Turkey looks for stability and a role that is more prominent within the powerful regional actors. The stability of Turkey and the Middle East are related in that, any choice that Turkey makes, for instance, when establishing a new government will not just shape the democracy of Turkey but could play a major role in various peace processes relevant towards returning stability in the entire Middle East (Bildt, 2015).

\section{IV.An Assessment of Turkey's Engagement in the Middle East Since 2002}

In the first term that is (2002-2007), JDP achieved outstanding success by elevating a declining Turkish economy by lowering the rate of inflation to 9 percent and by 


\section{QALAAI ZANISTSCIENTIFIC JOURNAL \\ A Scientific Quarterly Refereed Journal Issued by Lebanese French University - Erbil, Kurdistan, Iraq \\ Vol. (5), No (3), Summer 2020 \\ ISSN 2518-6566 (Online) - ISSN 2518-6558 (Print)}

creating a yearly economic growth rate of about 7-10 percent (Robins, 2007). Behind the moves on reforms towards liberal democracy, entailing JDP peace proposals to Turkey's Kurds, discussions for membership of the European Union (EU) started in 2005. Within the following two elections (2007-2015), the first celebratory period among JDP and relevant sections of the Turkish society and Turkey and its partners in the West slowly wore off due to the elections. In the 2007 elections, JDP won $46.5 \%$ of votes, which increased the electoral backing base by 12 percent. Such a landslide encouraged JDP to ask for 'ideological hegemony' over Turkish political site, with their Gulenist allies. For this to happen, they had to use solid grassroots. Although by $2015_{L}$ JDP stood at intersections of failure and success because of a deep split with their former Gulenist allies, anti-Kurdish strategies, and electoral losses. As a response, it employed strong survival strategies within a naked rivalry for political power, which provoked the coup try of 2016. Still, it made an assurance of increased AKP arrest of the country, changing the constitution of Turkey to favor the party and president and again an additional electoral success in June 2018 (Yuksel and Veen, 2018).

Turkey did focus on refining the ties it has with the Middle East and Balkans. These regions are the ones that Turkey conducts the majority of her businesses and takes part in development and aid projects. Bulent Aras, who is the administrator of the Strategic Research Center from Ankara, argues that the new strategy of Turkey is "to initiate a psychological breakthrough in the Balkans "to undo the negative memories of the past" (Aras, 2012, p. 11). In undertaking that, Turkey attempted to use soft power in improving monetary relationships through regional nations. Here, the current Turkish foreign policy aims at making use of historical and regional based politics being a catalyst towards an international spot (Byrant and Hatay, 2013). The soft power that Turkey has keeps growing because of how attractive it is to the neighbors from when JDP came to power. The products of Turkey, schools, televisions, and development aid have enhanced the soft power it has. As from 2002, TIKA has improved its activities plus the visibility it has through various assistance cooperation's undertaken abroad plus the thrust of current foreign policy enlargements of the Turkish Government and improvement in development. TIKA has 


\section{QALAAI ZANISTSCIENTIFIC JOURNAL \\ A Scientific Quarterly Refereed Journal Issued by Lebanese French University - Erbil, Kurdistan, Iraq \\ Vol. (5), No (3), Summer 2020 \\ ISSN 2518-6566 (Online) - ISSN 2518-6558 (Print)}

carried out various projects within the region, and such projects have improved the capacities in institutions. There is the Turkish Maarif Foundation (TMF), which is the current state-led institution in promoting the soft power and cultural diplomacy of Turkey. As of 2016, TMF has greatly contributed to transforming international education through a Turkey-centric viewpoint in over 40 countries (Akgun and Ozkan, 2020). Construction Corporation in Turkey is building various parts of Georgia.

The Middle East, despite being chaotic, is also relevant. Because of the religious and cultural importance, it has been the historical location where three main religions originated (Christianity, Judaism, and Islam), it continues being central to considerations of the foreign policy of the global powers. A very strong status quo in the Middle East was formed after World War II, one which has never changed. Torelli (2018) explains that, from 2002 to 2012, Turkey was regularly proposed as being a model for the Middle East and the Muslim world because of the achievements in democratization and economic development.

\section{Turkish-Syrian Relations}

A big change that has occurred in the Middle East is the fruitful revolution of conflictive relationships with Syria to more cooperative relationships. For example, Altunisik-Benli and Tür (2006) explain that, historically, the relationship between Syria and Turkey was terrible. For a long time, the known Ottoman heritage made up a relevant obstacle in developing close relations. During the cold war, these two countries lined up themselves with opposing blocs. This is part of what added to the poor relationship. As of 1998, relations among these countries kept transforming. And by 2000 , this was a time of building trust, majorly via security support. At such a time, conferences remained regularly held by the Joint Security Committee made of soldierly administrators as of each side, and the rise of diplomatic visits was witnessed on different levels. In 2004, the two nations signed a Free Trade Agreement, which was approved in 2007, and there was the establishment of a Turkish-Syrian Business Council which explored the prospect of enhancing relationships among. In this regard, the trade volume rose to two billion US dollars by 2008. Improvements in border trade led to economic development plus employment on each side. 


\section{QALAAI ZANISTSCIENTIFIC JOURNAL \\ A Scientific Quarterly Refereed Journal Issued by Lebanese French University - Erbil, Kurdistan, Iraq \\ Vol. (5), No (3), Summer 2020 \\ ISSN 2518-6566 (Online) - ISSN 2518-6558 (Print)}

Even with a huge rate of improvement, the upcoming growth of Syrian-Turkish relations will continue to undergo many challenges. How the trials are being handled is serious for this relationship to be sustained. Turkey started being afraid that Kurdish forces gained influence closer to the border of Turkey. For Erdogan, disputing PKK has taken priority over fighting the Islamic State (ISIS). "There is no real nationalist anger against ISIS, but there is nationalist anger against PKK" (O'Grady and Birger, 2019). Erdogan looks at Kurdish fighters within northern, eastern Syria like terrorists linked towards PKK. The relations did deteriorate due to the Kurdish issue in the border and especially after ISIS emergence.

\section{Turkish Iraqi Relations}

From history, Turkish-Iraqi relationships are very supportive. In the rule of the proWestern ruler in Iraq, immediately after liberation, these two republics closely collaborated and institutionalized their collaboration under Baghdad Pact that was founded in 1955. Even after the Arab nationalist Government, which collapsed this rule and removed the Pact, came to power, the relations remained intact (Çetinsaya, 2006). The various developments around Iraq from the Gulf Crisis have improved the relationships Turkey has with this country. Additionally, Turkey has created cooperative relations with every community within Iraq, plus the Kurdistan Regional Government (KRG). Turkey succeeded in cooperating on the PKK issues with Iraq and the US in 2008. Even with the improved Turkish-Iraqi relations, they continue to be fragile. There are instabilities in the Iraq political process. These kinds of instabilities cause a threat to the relations between Turkey and Iraq (Altunişik, 2006).

\section{Turkish-Iranian Relations}

The relationships between Turkey and Iran have been complex, followed by ideological and geopolitical rivalry plus a length of pragmatism that has fostered some collaboration. Following the Iranian Revolution, their relationship began being very complicated since the political rivalry was a relevant area of joint ties. From the 2000s, two major factors affected the relationship between Turkey and Iran. One is a new planned setting that arose at the beginning of the 2003 Iraq War (Calabrese, 2018). This helped in creating a shared perception of threat and contributed towards 


\section{QALAAI ZANISTSCIENTIFIC JOURNAL \\ A Scientific Quarterly Refereed Journal Issued by Lebanese French University - Erbil, Kurdistan, Iraq \\ Vol. (5), No (3), Summer 2020 \\ ISSN 2518-6566 (Online) - ISSN 2518-6558 (Print)}

reconciliation regarding issues of security. Second, the creation of the Turkish foreign policy to the Middle East underneath the rule of JDP resulted in the enhancement of relationships with Iran too. The inclusive policy of JDP administration on the Middle East entailed a need to having "zero problems with neighbors" plus emphasis in terms of diplomacy and financial interdependence (Larrabee and Nader, 2013, p. 46).

\section{V.TURKEY AND ARAB UPRSINGS}

Arab Spring Uprisings in the Arab world brought confusion not only to the countries affected but also Turkey. By challenging Turkey's foreign policy with respect to its ties with rebels and regimes, they undermined Turkey's credibility given that it pursued the zero problems with neighbour's policy. After many years of cooperative and diplomatic gains for Turkey, the Arab Uprisings introduced new problems to solve. During the pre-Arab uprising, Turkey had improved its close cooperation and trust with the Arab world that it became a role model to follow (Bagci and Acikalin 2015). The JDP regime's approach to human rights and freedom attracted the attention of the people in the Arab countries that they started to demand more freedom. When the uprisings broke out, Turkey's approach became inconsistent and confusing. In one hand, Erdogan hastily congratulated President Ahmadinejad of Iran on his victory in the elections of 2009 amidst allegations of fraudulent accusations by international observers (Bagci and Acikalin 2015). On the other hand, Erdogan called upon President Mubarak to resign when Egyptian uprising broke out.

In Syria's case, Erdogan seemed naïve in putting excessive faith in the relationship between Turkey and the regime of Assad before the uprising and then putting faith in supporting rebel groups with unclear political goals (Bagci and Acikalin 2015). These moves proved insignificant to Turkish interests and undermined its diplomatic capacity. Critics interpreted the uprising as the botched foreign policy of Turkey regionally. They see Davutoglu's vision of zero-problems policy as ineffective in promoting stability in the region. The Syrian uprising amounts to a serious setback for JDP and its zero-problems. 


\section{QALAAI ZANISTSCIENTIFIC JOURNAL \\ A Scientific Quarterly Refereed Journal Issued by Lebanese French University - Erbil, Kurdistan, Iraq \\ Vol. (5), No (3), Summer 2020 \\ ISSN 2518-6566 (Online) - ISSN 2518-6558 (Print)}

In the aftermath of the Arab uprisings, scholars debated whether Turkey should become the role model for the Arab world. When Arabic masses toppled the old dictatorships, Turkey emerged as a role model of democratization and as a proof that democracy and Islam can coexist. On the other, the uprisings demonstrated the length to which TFP was bestowed on authoritarian government. While JDP denied seeking to be model in the Middle East, it was inspiring to the region as many Arab countries turned to Turkey for inspiration. Syrian, Egyptian, Libyan and Tunisian uprisings stunned the Turkish elite and overwhelmed the foreign policy agenda of Turkey.

Critics have called into question the initially praised foreign policy of Turkey after the uprisings invalided the country's aspiration to become a key player regionally and globally (Bagci and Acikalin 2015). The wave severed close ties and cooperation Turkey enjoyed with its neighbors. With weighty justification, scholars have argued that the responses of Turkey have been inconsistent and muddled. Critics have pointed out that the uprisings revealed the shortcomings of the zero-problems policy. The upheavals also expose the capacity of Turkey to influence uprisings. The uprisings remind major players that the Middle East's complexity can overwhelm their agenda.

\section{CONCLUSION}

Conclusively, as can be seen in recent years, the relevance of Turkey being involved in the Middle East has changed. Turkey has gradually enhanced the relations it has with neighbors and has taken various third-party roles in the local struggles then extended the financial ties it has with the region. Such advances may be described through the attempt of JDP in developing a complete Middle East Policy then the interest it has within the region. JDP is very attracted to becoming involved dynamically in this region because of the importance it has on cultural and ancient ties through the Middle East plus expectations of political and economic benefits. Although the JDP policy just gives a partial explanation of the current involvement of Turkey in the Middle East. The exposed greater economic power that Turkey has 


\section{QALAAI ZANISTSCIENTIFIC JOURNAL \\ A Scientific Quarterly Refereed Journal Issued by Lebanese French University - Erbil, Kurdistan, Iraq \\ Vol. (5), No (3), Summer 2020 \\ ISSN 2518-6566 (Online) - ISSN 2518-6558 (Print)}

when compared to the other states shows that, if essential, Turkey may expand its military power quickly and more efficiently. Therefore, Turkey can play a role in stabilizing the Middle East due to the unique combination it has of Faith Force due to the strong army it has in the Islamic world and Finance. It is a determinant factor in stabilizing the Middle East. The stability is related to the Middle East because the Turkish Foreign Policy has attempted to be multidimensional, proactive, and even assertive with the priorities of its policy. The study did focus on the period from when JDP came to power until the presidential elections of 2018. After 2018, with the presidency system and Erdogan's only power, is very debatable if the same foreign policy has been applied or not, and it can be stated that Turkey may have moved to another period of its foreign policy. Therefore, to understand the Turkish foreign policy after 2018, there is a need for other studies to be analyzed, this can be a path for other researchers to study further.

\section{RECOMMENDATIONS}

If Turkey continues to maintain good relations with every player in the Middle East and gets to understand the limitations that its role brings, it will cause positive changes in the landscape of the Middle East. Since the result of Turkey's current position in the Middle East is received, it can only advance if the planned scenery is maintained, and if Turkey does not salvage from the entire process. If Turkey continues to grow rapidly, keeps cohesion, and properly handles the Kurdish issue, it may end up as a significant force that will change Middle East politics.

\section{REFERENCES:}

Akgün, M., Perçinoğlu, G., and Gündoğar, S.S., 2010. The perception of Turkey in the Middle East. TESEV PUBLICATIONS.

Akgun, B., and Ozkan, M., 2020. Turkey's entrance to international education: the case of Turkish Maarif Foundation. Insight Turkey, 22(1), pp.59-70. 


\section{QALAAI ZANISTSCIENTIFIC JOURNAL \\ A Scientific Quarterly Refereed Journal Issued by Lebanese French University - Erbil, Kurdistan, Iraq \\ Vol. (5), No (3), Summer 2020 \\ ISSN 2518-6566 (Online) - ISSN 2518-6558 (Print)}

Albarracín, J., 2012. The role of Turkey in the New Middle Eastern economic architecture.

Panorama, pp. 235-237. [online] Available at https://www.iemed.org/observatorien/arees-danalisi/arxius-adjunts/anuari/med.2011/Albarracin en.pdf

Altunişik, M.B., 2006. Turkey's Iraq policy: the war and beyond. Journal of Contemporary European Studies, 14(2), pp.183-196.

Altunisik-Benli, M. and Tür, Ö., 2006. "From Distant Neighbors to Partners? Changing Syrian-

Turkish Relations,", Security Dialogue, vol. 37, no. 2, pp. 229-248.

Aras, B., 2012. Turkey and the Balkans: new policy in a changing regional environment. German Marshall Fund on Turkey Analysis, 31. [online] Available at https://www.gmfus.org/publications/turkey-and-balkans-new-policy-changing-

regional-environment

Arı, T. and Pirinççi, F., 2010. Turkey's new foreign policy towards the Middle East and the perceptions in Syria and Lebanon. Journal of Gazi Academic View, 3(7), pp.1-16.

Bildt, C., 2015. 4 ways Turkey can help bring peace to the Middle East. Weforum.org. [online]

Available at https://www.weforum.org/agenda/2015/06/4-ways-turkey-can-helpbring-peace-to-the-middle-east/

Bryant, R., and Hatay, M., 2013. Soft politics and hard choices: an assessment of Turkey's new regional diplomacy (No. 2/2013). Peace Research Institute (PRIO).

Calabrese, J., 2018. Turkey and Iran: limits of a stable relationship. British Journal of Middle Eastern Studies, 25(1), pp.75-94.

Cengiz, D.i.N.C.., 2011. Turkey as a new security actor in the Middle East: beyond the slogans. Perceptions: Journal of International Affairs, 16(2), pp.61-80.

Çetinsaya, G., 2006. Turkey and the New Iraq. JSTOR. Insight Turkey, 8(2), pp.105-116.

Cook, S.A., Sabbagh, H.J. and Gwetzman, B., 2011. Turkey's rising Middle East role. Council on Foreign Relations, 26.

Criss, N.B., 2010. Parameters of Turkish foreign policy under the AKP governments. Revista UNISCI, (23), pp.9-22.

Davutoğlu, A., 2012. Principles of Turkish foreign policy and regional political structuring. Journal of Balkan and Near Eastern Studies, 16(4), pp. 404-418.

Davutogly, A., 2013. Zero problems in the New Era. Foreign Policy, 21. [online] Available at https://foreignpolicy.com/2013/03/21/zero-problems-in-a-new-era/

Dinçer, O.B. and Kutlay, M. 2012. Turkey's power capacity in the Middle East. International Strategic Research Organization (USAK), Report No. 12-04, June. 


\section{QALAAI ZANISTSCIENTIFIC JOURNAL \\ A Scientific Quarterly Refereed Journal Issued by Lebanese French University - Erbil, Kurdistan, Iraq \\ Vol. (5), No (3), Summer 2020 \\ ISSN 2518-6566 (Online) - ISSN 2518-6558 (Print)}

Hale, W., 1992. Turkey, the Middle East and the Gulf crisis. International Affairs, 68(4), pp.679-692.

Hinnebusch, R.A. and Ehteshami, A. eds., 2002. The foreign policies of Middle East states. Lynne Rienner Publishers.

Kardaş, Ş., 2012. From zero problems to leading the change: making sense of transformation in Turkey's regional policy. TEPAV-ILPI Turkey Policy Brief Series, 5(1), pp.1-8.

Kirişçi, K., 2009. The transformation of Turkish foreign policy: The rise of the trading state. New Perspectives on Turkey, 40(1), pp.29-56.

Kirişci, K., 2011. The Kurdish issue in Turkey: limits of European Union Reform. South European Society and Politics, 16(2). p. 335-349.

Larrabee, F.S. and Nader, A., 2013. Turkish-Iranian relations in a changing Middle East. Rand Corporation.

Lenore, M., 2009. Turkey and Gulf Cooperation Council security. Turkish Studies, 10(1), pp.7593.

Novosseloff, A., 2015. United Nations Interim Force in Lebanon (UNIFIL I). In The Oxford handbook of United Nations peacekeeping operations.

O'Grady S. and Berger M. (2019). Who are the Kurds, and why is Turkey attacking them? Washingtonpost.com. [online] Available at https://www.washingtonpost.com/world/2019/10/11/who-are-kurds-why-isturkey-attacking-them/

Robins, P., 2007. Between the EU and the Middle East: Turkish Foreign Policy under the AKP Government, 2002-2007. Milan: Instituto Per GliStudi di Politicialnternazionale.

Robins, P., 2014. The foreign policy of Turkey. The foreign policies of Middle East states, pp.315-336.

Sayari, S., 1997. Turkey and the Middle East in the 1990s. Journal of Palestine Studies, 26(3), pp.44-55.

Sözen, A., 2010. A paradigm shift in Turkish foreign policy: Transition and challenges. Turkish Studies, 11(1), pp.103-123.

Sluglett, P., 2005. The cold war in the Middle East. In L. Fawcett (ed.), International relations of the Middle East. Oxford: Oxford University Press, 2005, pp. 41-58.

Tol, G., 2012. The "Turkish Model" in the Middle East. Current History, 111(749), pp.350-355.

Turkish Ministry of Foreign Affairs. [online] Available at http://www.mfa.gov.tr/synopsis-ofthe-turkish-foreign-policy.en.mfa, 


\section{QALAAI ZANISTSCIENTIFIC JOURNAL \\ A Scientific Quarterly Refereed Journal Issued by Lebanese French University - Erbil, Kurdistan, Iraq \\ Vol. (5), No (3), Summer 2020 \\ ISSN 2518-6566 (Online) - ISSN 2518-6558 (Print)}

Torelli, S.M., 2018. The rise and fall of the Turkish model for the Middle East. In Turkey's relations with the Middle East. Springer, Cham. pp. 53-64.

Yörük, Z. and Vatikiotis, P., 2013. Turkey, the Middle East and the media| soft power or illiiusion of hegemony: the case of the Turkish soap opera. Colonialism. International Journal of Communication, 7, p.25.

Yuksel, E. and Veen, V. E., 2018. Turkish foreign policy towards the Middle East from 2002 to 2018. Clingelandael.org. CRU Report July 2018. Chapter 1.

\section{توركيا وهى فاكتهريّكى دياريكر او بوّ ساdقامكيركردنى روّز هلَّاتى ناوهر است}

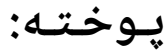

ئامانجى ئهم تويّزينهوهيه ناساندنى ئهگهرى ئهوهيه ئهگهر بتواندريّت توركيا ببيّته هوّكاريّكى

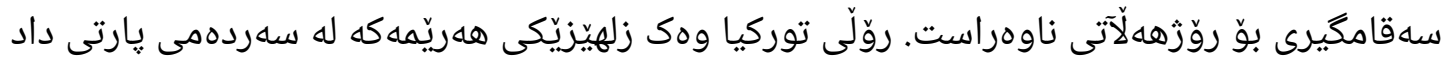
و گهشهيِدانى زيادى كردوه. سهركردايهتى ئاكهيه ناخوازيّت تهنيا وهك هيّزيّكى ههريّمى بميّنيّتهوه،

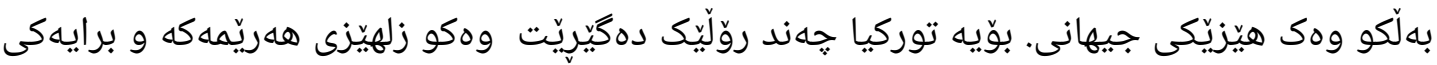
ميّزووييمهزن تهماشا بكريّت بيّجكه له خوّنواندن وهك قه لَغانى كوّمهله ئيسلامييهكان.. رؤلهكانى ترى توركيا كه بهدهستى خستوون وهك هاوئاههنكاكر و نيّوبريّيوانيكار بوّ دروستكردنى سهقامكيريى له عيّراق، سوريا و تيّكراى روَّههلْاتى ناوهراست. ميتوّد و ريّكهى تويّزينهوه و كه بهكارهاتووه ريّكهى جِوّنيهتى بووه به سوود وهرگرتن له سهرجاوه لاوهكييهكان. كهإن به نيّو دهقى نووسينى نووسهرهكانى يِيّوو و تويّزينهوهكان كه تواندراوه بهدهستبخريّن له جوارجيوهى وردى خوّيان بهكاربهيّندريَّن بوّ شيكردنهوهى روّلَى توركيا به ئامانجى سهقامكيرى له روّزههلاّتى ناوهراست. 


\section{QALAAI ZANISTSCIENTIFIC JOURNAL \\ A Scientific Quarterly Refereed Journal Issued by Lebanese French University - Erbil, Kurdistan, Iraq \\ Vol. (5), No (3), Summer 2020 \\ ISSN 2518-6566 (Online) - ISSN 2518-6558 (Print)}

له زيّر روّشنايى تويّزينهوهى ئيّستا، توركيا جهند روّلَ و ههولِيّكى داوه به ئامانجى باشتر كردنى

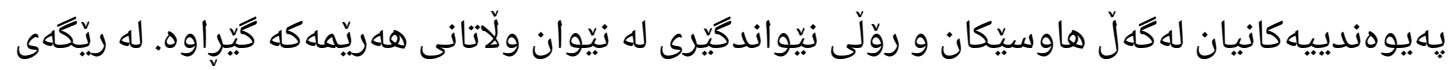
سياسهت و يهيوهندييهكانى دهرهوه توركيا توانيويهتى يهيوهندى باش دروست بكات. بوّ توّكمهكردنى سهقامكيرى روّزههلآتى ناوهراست، توركيا يشت به يهيوهندى باش دهبهستيّت له ناوجهكه كه ههمان كيشه و ئاستهنكيان ديّته ييش. به شيووهيهكى نمونهيى يهيوهندى باش له جياهنى سياسهتدا زينكهيهكى يهسهند دروست دهكات بوّ ولّاتان تا ههولى يهكخستنى نهتهومكان

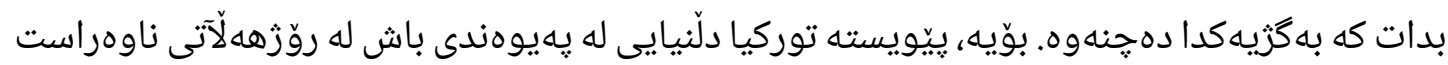

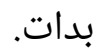
جهمكه سهرهكييهكان: شهرِى سارد، توركيا، روّزههلاّتى ناوهراست، هيّزه ههريّمييهكان، سياسهتى دهرogos

\section{تركيا كعامل حاسم لتحقيق الأستقرار في الشرق الأوسط}

كان الهدف من هذه الدراسه تحديد إذا كانت تركيا يمكن أن تكون عاملا حاسما في تحقيق الاستقرار في الشرق الأوسط او لا. ازداد دور تركيا كقوة إقليمية منذ صعود حزب التنمية و العدالة إلى السلطة. لم تطمح قيادة حزب العدالة والتنمية أن تكون قوة إقليمية فقط ، بل لتكون قوة عالمية. فهكذا ، قامت

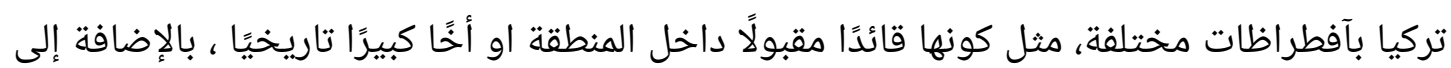
التعامل كدرع للمجموعات الإسلامية. الأدوار الأخرى التي حصلت عليها تركيا هي دور الوسيط في محاولتها خلق الاستقرار داخل العراق وسوريا وداخل الشرق الأوسط بأكمله. 


\section{QALAAI ZANISTSCIENTIFIC JOURNAL}

A Scientific Quarterly Refereed Journal Issued by Lebanese French University - Erbil, Kurdistan, Iraq

Vol. (5), No (3), Summer 2020

ISSN 2518-6566 (Online) - ISSN 2518-6558 (Print)

الطريقة التي استخدمت في جمع المعلومات و الابحاث هي الطريقة النوعية واستخدام المصادر الثانوية. تمكنت الباحثت من خلال دراست للابحاث السابقة التي أجراها مؤلفون آخرون ، و ايظا الحصول على المواد ذات الصلة واستخدمها في سياق البحث وشرح كيفيت تلعب تركيا ادوارها البارزة في تحقيق الاستقرار في الشرق الأوسط. في ضوء الدراسة البحثية الحالية ، بذلت تركيا جهودًا مختلفة لتحسين العلاقات مع جيرانها ولعبت دور الوسيط في الشرق الأوسط. من خلال السياسة الخارجية ، عززت تركيا العلاقات الجيدة داخل الشرق الأوسط. لتعزيز الاستقرار في الشرق الأوسط ، يجب أن تحافظ تركيا على علاقات جيدة مع مختلف البلدان في مواجهة التحديات التى توابـ النطقت. من الناحية المثالية ، وجود العلاقات الجيدة في المجال السياسي بى بيئة مهيئت للبلدان التي تسعى لتوحيد الدول المتحاربة. وبالتالي ، ينبغي أن تضمن تركيا علاقات جيدة لتعزيز الاستقرار في الشرق الأوسط. 